удК 351.853

\title{
ACTUAL PROBLEMS OF MANAGEMENT OF CULTURAL HERITAGE IN UKRAINE
}

\section{АКТУАЛЬНІ ПРОБЛЕМИ УПРАВЛІННЯ КУЛЬТУРНОЮ СПАДЩИНОЮ В УКРАЇНІ}

\author{
Safonov Yurii \\ Institute of Education Content Modernization \\ of Ministry of Education and Science of Ukraine \\ ORCID: https://orcid.org/0000-0001-5623-1965 \\ Datsko Olesya \\ Faculty of History and Theory of Arts, Lviv National Academy of Arts \\ ORCID: https://orcid.org/0000-0002-6713-1158
}

\begin{abstract}
The article focuses on the problems of public management of cultural heritage sphere in Ukraine, including challenges of heritage management in museums and cultural reserves. Te main aim of this paper is to identify the problems and challenges of cultural heritage management in Ukraine that require reform in the first place. The main conclusion of this article is that Ukraine urgently needs to reform such areas of cultural heritage managementas: functioning of the registration and information database on cultural heritage, ensuring effective protection of historical buildings, their surroundings and landscape, solving land use problems and conflicts with businesses, improving the technical conditions of historical buildings and surrounding infrastructure, significant reform of managementof museums and cultural reserves. All these measures should be supplemented by ensuring that state autorities respond quickly to violations of laws on the protection of cultural heritage and that punishment for violators of the law is unavoidable. Without these measures, the risk of losing a large number of cultural heritage sites in Ukraine today is very high.
\end{abstract}

Keywords: management, cultural heritage, heritage management, cultural heritage protection, Ukraine.

Introduction. Protection of cultural heritage is one of the main tasks of public management in any state. This activity is particularly important in the concept of sustainable development in the context of the principle of equal rights to cultural heritage for current and future generations of citizens. Today, an effective public policy in this area can not only ensure the reliable preservation and transfer of the cultural heritage unchanged to future generations, but also transform it into a specific economic resource. The heritage resource, without being destroyed or losing its qualities, can now act as a driver of economic development, for example, in such areas as tourism, creative industries, science and education, crafts, construction and reconstruction, real estate, etc. This is confirmed by the experience of such European countries as Italy, France, Austria, Greece, Spain, Netherlands, Czech Republic, etc.

However the situation in cultural heritage public management in different regions of Europe is very different. In post-socialist and especially post-So- viet countries in Central and Eastern Europe, the process of forming national systems of public management of cultural heritage is often still incomplete and is at different stages depending on the country. The situation here is complicated, on the one hand, by the level of economic development of these countries and, consequently, often by the small funds that states can allocate from the budget for the protection and restoration of heritage. On the other hand, public policy and administration of cultural heritage in these countries is still largely guided by the previously existing paradigm of cultural heritage. The previous paradigm of cultural heritage did not consider it as a resource or a driver of economic development, but interpreted it as an economic ballast that does not bring any benefits, but constantly requires funds from the budget. This attitude to cultural heritage also unfortunately still exists in some countries and among some political and public figures. In reality, the problems are much greater. And without their definition it is impossible to develop an effective plan for the reform of pub- 
lic policy and management of cultural heritage in these countries.

Ukraine today seeks to implement reforms in many areas of public life in order to learn from the successful European experience and get closer to developed countries in this regard within the framework of the EU integration processes. In this situation, the reform of public policy and administration of cultural heritage should become an integral part of the overall reform plan. Based on the above, the main aim of this article is to identify such problems and challenges of public policy and administration of cultural heritage in Ukraine that require reform in the first place. Achieving this aim will provide important information for developers and implementers of the public policy and administration reform program.

\section{Registration and Information Database for Cultural Heritage}

Ukraine, both in absolute and relative terms, is one of the countries with a rich cultural heritage. But recently there has been a steady decline in the number of heritage sites in Ukraine. And this trend is not directly related to the war and Russia's occupation of the Crimea and part of the Donbass. In 2011-2012 there were 144.8 thousand registered heritage sites in Ukraine. And already in 2013, their number decreased by 2 thousand to 142.8 thousand, in 2014-2015 it decreased by almost 20 thousand more up to 123.6 thousand (Mazur, 2018). In 2016-2019 the decline in the number of heritage sites continued at the same (if not greater) rate. This is a consequence of the fact that Ukraine today has not formed an effective and adequate system of cultural heritage public management. First of all, the country lacks the important institutional, organizational and financial conditions for the preservation of cultural heritage guaranteed by the Ukrainian Constitution. This ultimately leads to a reduction in the number of heritage sites due to their destruction under the influence of natural and anthropogenic factors.

One of the most important problems in the field of cultural heritage registration in Ukraine today is the lack of a complete and exhaustive State register of immovable monuments, which has been under development in the Ministry of Culture for almost 20 years. Although the procedure for determining the category of a heritage object for inclusion in this register was approved by the Cabinet of Ministers in 2001 (Bohutskyy, 2009). The consequence is that the state authorities do not have complete and reliable information about the number and physical condition of these objects.
As a result, there is an institutional gap in Ukraine that has far-reaching implications for public management. The fact is that according to the law on the protection of cultural heritage, only the object that is included in the State register of immovable monuments of Ukraine can be considered a heritage monument. This register includes only about 8 thousand objects that are monuments of history, archeology and monumental art, of which less than 1 thousand are monuments of national significance, and others have only the status of monuments of local significance (Ministry of Culture of Ukraine, 2020). At the same time, the register did not include any Ukrainian heritage sites of national significance that are located on the territory of the Kyiv Pechersk Lavra (World Heritage site), which has the status of a national reserve. Although there are 48 cultural heritage sites of national significance on the territory of this monastery. Also, the register did not include any object of the national reserve "Sophia of Kyiv" (Saint Sophia Cathedral in Kyiv, also a World Heritage site), which has 38 heritage sites of national significance. At the same time, the register includes only 2 objects of the reserve "Sophia of Kyiv" and 85 objects of the reserve "Kyiv Pechersk Lavra" and only in the category of monuments of local significance.

The situation is complicated by the fact that neither laws nor other acts of state authorities have fixed a specific form of this register. As a result, the Ministry of Culture has been adding information to the register for almost 20 years that may no longer be relevant, not sufficiently complete, or not suitable for making effective management decisions.

Moreover, the Ministry of Culture does not have some data on individual heritage sites and their entire groups that are already included in the register. This is, among other things, basic information about the number of objects, as well as information about their cost. This applies, for example, to the objects of the national reserves "Old Halych" (46 objects), "Pereiaslav" (20 objects) and "Castles of Ternopil region" (8 objects), although all of them are already included in the register.

A significant disadvantage of the system of registration of cultural heritage objects in Ukraine, which are stored in museums and cultural reserves, is that all of them are accounted for by storage groups only in quantitative terms. The legislation of Ukraine does not provide for determining the value of registered cultural heritage objects. Because of this, it is now impossible to determine the value of, for example, stolen or 
destroyed heritage objects. In addition, according to Ukrainian accounting standards, both individual objects of cultural heritage that are stored in museums, and entire collections that are main part of the State Museum Fund, are not accounted for and are not reflected in the financial statements (Ganski, 2019).

\section{Protection of Cultural Heritage Sites}

Protection of cultural heritage in Ukraine is defined at the highest legal level - in the Constitution (Constitution of Ukraine, 1996.). It defines the preservation of heritage monuments and all objects of historical and cultural value as one of the primary tasks of the state, and also obliges the state and all its institutions to use all available measures to return to the country cultural values that were illegally exported abroad.

One of the tools for cultural heritage protection, the use of which today in Ukraine causes the most controversy and discussion, is the regime of property rights to cultural heritage sites. The most valuable historical and cultural heritage objects are included in the Non-Privatization List of Cultural Heritage Sites. The leader in the number of heritage sites included in this list is Kyiv (322 sites), followed by Vinnytsia region (211), Lviv region (175), Khmelnytskyi region (162), Ivano-Frankivsk region (130) and Volyn region (108) (Law of Ukraine, 2009).

Despite the existence of a regulatory document on the procedure for issuing certificates of registration of a heritage site as a monument, approved almost 20 years ago, the Ministry of Culture has not issued any certificate of registration of a heritage site as a monument to owners of historical buildings. This creates a situation where no institution or organization that has a cultural heritage object on its balance sheet can confirm the inclusion of information about it in this register, and, consequently, confirm the building's status as a cultural heritage monument.

On this basis, it can be argued that the Ministry of Culture does not fully comply with the requirements of legislation on the protection of cultural heritage and does not provide proper information and documentation support for cultural heritage public management. This can negatively affect the preservation of the heritage and its effective use in conditions of uncertainty about the status of the historical building and, consequently, the lack of legal obligations of its owners.

The situation is particularly dramatic in the sphere of concluding protection contracts for historical and architectural monuments. Protection documents for the objects of the national reserve "Homeland of Taras Shevchenko" are not concluded at all. The greatest resonance in the media and society was the information that the security documents for the objects of the Kyiv Pechersk Lavra were not signed. These are 12 monuments, including those of national significance, included as a single complex in the UNESCO World Heritage List. Today they are in the use of the Orthodox Church of the Moscow Patriarchate, which conducts numerous illegal construction works on this site.

The Ministry of Culture has concluded more than 600 protection documents for objects of cultural heritage of national significance, which is only one-third of the required volume (Kharkovenko, 2017).

Among other important manifestations of the lack of full and timely performance of its duties by the Ministry of Culture in the field of cultural heritage public management, we should mention the inadequate response (and often lack of response) to violations of legislation. There are a lot of examples here, so we can only remember the most illustrative ones. Five years ago, the National historical and ethnographic reserve "Pereiaslav" officially notified the Ministry of Culture of the facts of gross violation of the law by the parish of St. Michael of the Orthodox Church of the Moscow Patriarchate regarding the cultural heritage site of national significance - the Church of St. Michael in Pereiaslav. In 2010-2013, under the Pro-Russian President Viktor Yanukovych, this object was temporarily transferred to the use of an Orthodox parish in violation of the law. Although earlier it for more than 50 years housed the Museum of Ukrainian Folk Clothing of the Middle Dnieper Basin of the late XIX - early XX century. Later, the Orthodox parish began to carry out largescale construction works on this cultural heritage site without any permits provided for monuments of national significance, without the relevant scientific and design expertise and documents. All this in the end greatly changed the exterior of the unique historical building of 1649 . There was no response from the Ministry of Culture, other state authorities, the police and the Prosecutor's office.

These facts of inaction of state authorities regarding non-compliance by users of historical buildings with the laws are not isolated, but are today of a systemic nature. Another example is the National reserve "Kyiv Pechersk Lavra" has repeatedly appealed to the Ministry about the fact that a number of institutions and organizations located in historic buildings that are heritage sites of national importance and a part of reserve, without any documents which would confirm legality of use. 
Violation of the legislation in the field of cultural heritage protection has become so common in Ukraine today that it is violated even by those institutions and organizations that should monitor compliance with the law in this area. For example, the Ukrainian Society for the Protection of Historical and Cultural Monuments has renovated and redeveloped more than $300 \mathrm{~m}^{2}$ of the historical building, which is part of the Kyiv Pechersk Lavra complex (Radio Liberty, 2017). The works carried out by this society directly contradicted the protection agreement signed in 1996 and were carried out without the permission of the Ministry of Culture and the national reserve.

\section{Land Use Problems and Conflicts in the Cultural Heritage Sphere}

The Ukrainian system of cultural heritage public management today is so inefficient that it is not even able to establish the status of land under historical buildings or territories of cultural reserves. For example, the law stipulates that the territories where reserves are located must be included in land use plans, land management projects, as well as other design and planning documents and documents of an urban nature, in the state land cadastre. However, today the status of such land is not defined even for the site where the national reserve "Sophia of Kyiv" is located. Moreover, this plot is not even included in the state land cadastre.

State control over the use of historical and cultural lands is not carried out in Ukraine today due to the lack of an appropriate mechanism. As a result, there are widespread facts that reserves and museums do not have legal documents on the use of their land plots (they are often replaced in practice by the decision of the local municipality). For example, these documents are completely absent from the cultural reserves in Kyiv and Zhovkva (Lviv region), and only partially available in the reserves "Hetman's capital" (Baturyn, Chernihiv region), "Khotyn Fortress" and "Pereiaslav". And the cultural reserve "Khortytsia" received a permit from the Zaporizhia Municipality for the right to permanent use of land only five years after the entry into force of the relevant law. At the same time, on the basis of the right of permanent use, the reserve actually owns only about $20 \%$ of the total land area for which there is a corresponding document. Today, there are still unresolved issues of legal registration of the status of the territory of the Khortytsia island (on the Dnieper), which is owned by businessmen who are not related to the reserve, as well as issues of unauthorized seizure and unauthorized construction of 53 residential houses on the reserve, whose residents do not have any documents that would confirm the legality of building houses and the legal status of land. Despite the fact that any housing construction on the territory of the reserve is prohibited by law (Radio Liberty, 2009).

Mechanisms and procedures for state control in the sphere of protection and use of cultural heritage are specified in the law on basic principles of state control in the business sphere from 2007 (Law of Ukraine, 2007). The moratorium on inspections of business entities (Cabinet of Ministers of Ukraine, 2014), which was introduced in 2014 by Prime Minister Arseniy Yatsenyuk, effectively paralyzed state control in the sphere of effective administration and use of cultural heritage. The moratorium not only did not lead to the harmonization of relations, but actually became a real threat to the very existence of both the heritage sites themselves, as well as their architectural environment and historical landscape. The lack of control mechanisms activated dishonest developers and other businessmen whose interests also affected the sphere of cultural heritage. However, even the intervention of the police and other state authorities and bringing the perpetrators to justice (often very symbolic) in most cases will not allow to restore the violated original position and lost (damaged) objects of cultural heritage, their elements, environment or historical landscape.

The greatest value and the greatest potential are historical buildings that have been preserved not as a separate object, but as an element of a complete historical ensemble and landscape (Ganski, 2018). In order to preserve the authentic character of the space for individual heritage sites, their complexes, ensembles and reserves around them, special zones must be defined in accordance with the law: protection zones, zones of regulated development, zones of protected landscape, as well as zones of protection of the archaeological cultural layer. The boundaries and modes of business use of these territories are established by specially developed research and project documentation and approved by the relevant government authority.

More than ten years ago, the Ministry of regional development, construction and communal services developed a special document to regulate relations in this area called "The Composition and Content of Project Documentation for the Definition of Boundaries and Usage Regimes of Zones of Protection of Architecture and Urban Planning Heritage Monuments" (National Stand- 
ard of Ukraine, 2017). According to the law on the cultural heritage protection (Law of Ukraine, 2000), the regime for the use of cultural heritage sites is determined by the central executive authority, which implements public policy in the field of preservation, recording, protection and use of cultural heritage in relation to objects of national significance (Ministry of Culture), and in relation to local heritage sites - regional and city state administrations.

Despite the requirement of the law, the Ministry of Culture has not yet approved the procedure for defining and approving the boundaries and use of heritage protection zones. Only 16 cultural reserves today have clearly defined protection zones and use regimes. In reserves "Homeland of Taras Shevchenko", "Kachanivka", "Chyhyryn", "Field of the Battle of Berestechko", "Hlukhiv", Belz and Zhovkva reserves, as well as in Uman today there are no security zones. This situation carries risks of unauthorized development of the historical landscape and surrounding territories.

Although cases of unauthorized construction near valuable historical buildings are not isolated, but are of a mass nature. For example, on the territory of the National Historical and Architectural Reserve in Berezhany (Ternopil region) for several years there is a store and an unauthorized entertainment area of about 0.5 thousand $\mathrm{m}^{2}$, which have nothing to do with the reserve. Another example of non-legal capture of the territory of reserves: despite the decision of the Supreme Court, a businessman illegally placed a shop and cafe with an area of $150 \mathrm{~m}^{2}$ on the territory of the Shevchenko National Reserve in Kaniv (Cherkasy region) (Mazur, 2018). Despite numerous appeals from the reserve administration to the Prosecutor's office and police, illegal shops and cafes continue to operate on the territory of the reserve today.

It cannot be said that the Ministry of culture did not carry out any work in this area at all. But their slow pace, inconsistent and contradictory nature cause a lot of complaints from experts and the society. So, back in 2011, the Ministry approved project documentation designed to regulate the boundaries and use of the protected area of the St. Sophia Cathedral and the Kyiv Pechersk Lavra with the surrounding territories and buildings that are World Heritage sites. But the Ministry did not provide the relevant information to the UNESCO headquarters in Paris.

A protected area is an area where, in order to ensure the preservation of historical buildings in their authentic surroundings, a special regime is established for the use of the territory, which restricts business and prohibits construction. For example, an order of the Kyiv City State Administration in 2002 established that the protected areas of heritage sites in Kyiv are subject to the principles of restoration, rehabilitation and regeneration regime with limited transformation of the historical environment (Harnyk, 2002). It is allowed to build only in exceptional cases and only particularly important buildings for the relevant projects, which are limited by number of storeys, taking into account the architecture and general silhouette of the city.

For example, the St. Sophia Cathedral complex in Kiev is one of the most valuable heritage monuments in Ukraine and has the status of a UNESCO World Heritage site. At the same time, today there are as many as 4 construction projects in the immediate vicinity of the St. Sophia Cathedral, which are not approved by UNESCO, but are under development or already under construction (Kovalskyy, 2020).

Such actions that actually destroy the historical environment around a unique heritage site and threaten its existence have become possible, including due to the imperfect institutional environment and the lack of effective mechanisms for cultural heritage public management. First of all, Ukrainian legislation is very vague about the requirements for stopping and prohibiting construction in protected areas of heritage sites. The current situation creates conditions for the inclusion of such an object in the UNESCO List of World Heritage in Danger. All this has a very negative impact on the international image of the country, primarily the tourist image.

The city authorities of Kyiv were forced to intervene in this situation, despite the fact that this object belongs to monuments of national significance. By the decision of the Kyiv City Council a temporary moratorium was imposed on both the sale of land plots and construction works (Kyiv City Council, 2015). This measure must be in effect until the appropriate zoning plan is approved for the central planning zone of the city and a detailed plan of the territory within the buffer and protection zones of both the St. Sophia Cathedral and the Kyiv Pechersk Lavra. Unfortunately, even despite the decision of the Kyiv City Council and this moratorium, construction work in the security zone of the St. Sophia Cathedral soon continued. The same situation was repeated in relation to the protection zone of the Kyiv Pechersk Lavra. A house was built next to this monastery, for which the developer did not receive any construction permits or 
approved project documentation. As a result, the reserve administration's appeals to the Prosecutor General's office and the Ministry of culture did not bring the desired results. And this case is not an isolated one.

In this situation, there is a violation of not only the norms of Ukrainian legislation, but also international law. Since construction in the immediate vicinity of the St. Sophia Cathedral without informing the World Heritage Committee through the UNESCO Secretariat is contrary to the international obligations adopted by Ukraine, as set out in the Convention for the Protection of the World Cultural and Natural Heritage. According to this Convention, the state is obliged to inform UNESCO about any repair, and especially construction works in the protected area. It is obvious that the Ministry of Culture does not respond properly to the construction in protected areas and illegal seizure of reserve territories, unauthorized work to change the appearance of historical buildings, changes in historical landscapes, etc. Thus, the lack of reaction from state authorities contradicts not only Ukrainian legislation, but also the norms of international law. Therefore, there is every reason to talk about the inefficiency of both individual institutions in the sphere of public management and the entire system.

\section{Technical Conditions \\ of Historical Buildings}

Today, 185 objects (buildings and structures) of cultural heritage of national significance (294 total) and 416 objects of local significance (506 total) are in satisfactory technical condition in Ukraine. More than 40 objects of national significance and 11 objects of local significance are in disrepair, which is $14 \%$ and $2.5 \%$ of their total number in the country. Another 63 objects of national significance and 79 objects of local significance are currently in poor condition, which is $22 \%$ and $16 \%$ of their total number, respectively. More than 200 monuments of national significance from 21 reserves, as well as more than 100 monuments of local significance require urgent restoration $(77 \%$ and $21 \%$ of the total number in the country, respectively) (Mazur, 2018).

Insufficient funding for repair and restoration works is observed even at sites on the UNESCO World Heritage List. The condition of individual objects and complexes of the national reserves "Sophia of Kyiv" and "Kyiv Pechersk Lavra" is getting worse every year, and the necessary repair and restoration, conservation and strengthening works are not provided for from the state budget. Although these objects are located in zones of active influence of man-made and natural factors, which can create a threat of their destruction. For example, the unsatisfactory condition and high degree of wear of urban water supply and sanitation systems leads to an increase in the level of ground water and creates a threat of flooding of the unique complex of St. Sophia's Cathedral in Kyiv.

In the sphere of cultural heritage public management there is a lack of mechanisms for enforcement of decisions of state authorities. For example, 15 years ago, Kyiv authorities banned the entry of cars to a particularly valuable part of Sophia square (Kyiv City Council, 2005). This order is constantly violated, and no sanctions are applied to violators. Although, according to experts, the movement of cars, their unauthorized parking and exhaust create harmful vibration loads and negatively affect the cultural heritage sites of world significance - St. Sophia mosaics and frescoes.

Today, almost 30 objects of historical buildings of the Kyiv Pechersk Lavra are in disrepair or unsatisfactory condition. The territory of this cultural reserve is located in a landslide zone, the danger is increased by the unsatisfactory or even emergency condition of the city's water supply and sanitation systems, which are laid on the territory of the reserve and adjacent streets. The long-term lack of necessary repairs due to lack of funding threatens to destroy both individual objects and the entire complex of unique world heritage sites. This is the situation in the capital, and in some regions the situation is even worse.

\section{Cultural Heritage Management in Museums and Cultural Reserves}

The main direction of the national museum policy in Ukraine is declared to be the preservation and support of the museum fund. This is stated in the Law on Museums and Museum Activity (Law of Ukraine, 1995). But only 6 historical and cultural reserves are included in the List of Museums that store museum collections and items from state ownership and that belong to the state part of the museum fund of Ukraine (Mazur, 2018). These include the national reserves "Sophia of Kyiv", "Kyiv Pechersk Lavra", "Pereiaslav", "Khortytsia", "Old Halych", as well as the reserve in Zbarazh. But the law on museums and museum activity concerns all types of museums, however cultural reserves only in sphere of the processes of Museum identification, protection, restoration and conservation, accounting, protection and use of museum items and collections. This requires the adjust- 
ment of existing legal norms and the development of modern, better laws.

In Ukraine, there are still a number of significant gaps in the cultural heritage public management after 30 years of independence. For example, the Ministry of Culture has not developed a standard form of instructions for storing, recording and using museum collections and objects. Although this was still provided for by the Regulations on the Museum Fund of Ukraine in 2000 (Cabinet of Ministers of Ukraine, 2000) and was confirmed by a resolution of the Cabinet of Ministers in 2010 (Cabinet of Ministers of Ukraine, 2010). As a result of this institutional gap, cultural heritage institutions used the Instruction on the Recording and Storage of Museum Valuables, which was approved in the USSR (1985).

Due to the inaction of the central government body in this area, in violation of the requirements of laws, the management of reserves has not yet resolved the issue of effective use of cultural heritage that are in their custody. Now in the cultural reserves subordinated to the Ministry of Culture, there are more than 600 thousand heritage objects attributed to the main museum fund, of which about 500 thousand objects are placed in storages (Polyvach, 2012). Only over the past five years, the customs authorities of Ukraine have identified and transferred to cultural reserves more than 0.5 thousand items of cultural heritage, which in most cases were placed in museum storages. Although such storages often do not meet the requirements of the law. For example, require immediate repair of storage facilities of the Kyiv Pechersk Lavra (about 1 thousand $\mathrm{m}^{2}$ ), reserves "Pereiaslav" (more than 0.5 thousand $\mathrm{m}^{2}$ ), "Kachanovka" (about 0.2 thousand $\mathrm{m}^{2}$ ), etc. (Mazur, 2018). Physical and climatic conditions in these premises do not meet the requirements for storing museum items, and in the Kremenets-Pochaiv Reserve and in the Belz Reserve, there are no storage facilities at all.

One of the most important problems of preserving cultural heritage in museums is total non-compliance with storage conditions. Humidity and temperature regimes are not observed on a large scale due to the absence or improper functioning of air conditioning systems, emergency lighting systems do not work, etc. Among the problems of preserving heritage in museums, the issue of security occupies an important place. Despite the requirements of the law, 8 cultural reserves do not have an alarm system against unauthorized entry, 5 reserves do not have bars on their windows, and 8 reserves do not have reinforced doors. All this increases the risk of theft of heritage objects.

As a result, the number of museum items that are in the process of destruction is about 18 thousand. And about 70 thousand museum items require urgent restoration to prevent their complete destruction. Most of these cases were recorded in the reserves "Kyiv Pechersk Lavra" and "Pereiaslav" (12 thousand and 14 thousand, respectively). The slow pace of restoration works, caused by lack of funding, lack or small number of necessary specialists, can lead to the loss of a significant number of cultural heritage sites in the future (Kazlouski and Ganski, 2018).

One of the forms of public control over the preservation of valuable items stored in museums and cultural reserves is the verification of accounting documentation with the actual presence in these institutions of items from the state part of the museum fund of Ukraine. However, due to the lack of effective management decisions on the part of the central government authority, this process has not yet been completed. Although this procedure has been carried out in 16 cultural reserves over the past 15 years, only 10 such procedures have been approved by the Ministry. As of today, the process of verification of funds in the Shevchenko National Reserve, as well as in the reserves "Babi Yar" and "Pereiaslav" has been completed by more than $50 \%$. There is no information about the beginning of these procedures in the reserves in Khotyn, Kremenets and Belz today. At the same time, in the national reserve "Pereiaslav" during such events, more than 3 thousand unaccounted objects were identified, and in the Kyiv Pechersk Lavra almost two dozen museum items and products made of precious metals (Mazur, 2018).

An urgent problem of the system of cultural heritage public management in museums is the inefficient organization of space. Due to the lack of museum spaces in Ukraine today less than $10 \%$ of the total number of museum items is available for tourists to view. For example, the national reserve "Sophia of Kyiv" exhibits only $6 \%$ of items (i.e. 5 out of 80 thousand). At the same time, almost $30 \%$ of all the reserve's premises are occupied by 5 institutions whose sphere of activity is not related to the reserve in any way. Moreover, these institutions also earn money by subleasing the reserve's premises. For example, the Ukrainian Society for the Protection of Historical and Cultural Monuments, which leases more than 2.5 thousand $\mathrm{m}^{2}$ of premises from the cultural reserve, sublets almost $20 \%$ of them to 12 outsiders, which directly contradicts 
the terms of the protection agreement (Accounting Chamber of Ukraine, 2015). Thus, there is a lost profit for the reserve, which is the result of inefficient management.

The country does not have a system of planning, information and methodological support for the cultural heritage public management. Museums and cultural reserves operate on the basis of plans and programs, the results of which must be reported to the Ministry of culture for analysis and effective management decisions. However, these reports do not have a clear and uniform structure, and the vast majority of indicators are unsuitable for further comparisons, and, consequently, for use in management practice.

Conclusions. Despite the fact that the preservation, protection and effective use of cultural heritage is among the international legal obligations of Ukraine to the international community and is a moral duty to future generations of Ukrainians, the system of public management in this area is extremely inefficient and not does ensure the implementation of even the most basic requirements and standards. The interest in heritage on the part of state authorities is only declarative. Challenges of protection and rational use of heritage in museums and cultural reserves are not considered by the boards of the Ministry of culture and meetings of the Cabinet of Ministers. Only one parliamentary hearing on this issue has been held in the past 10 years. This indicates that there is no real interest on the part of the state in cultural heritage issues. The state does not yet understand the significant resource potential of cultural heritage and does not attempt to activate and use it effectively.

The most significant problems of cultural heritage public management in Ukraine today are: a) the lack of complete, reliable, representative and up-to-date information about all cultural heritage sites, the absolute uselessness and lack of information in the existing register; b) inaccurate legal status of many historical buildings and territo- ries, mass lack of necessary security agreements and documents for historical buildings that would clearly define the responsibility of their owners; c) destruction of the historical environment and landscape of many cultural heritage sites, especially in major cities, due to the actions of businessmen and developers; d) inefficiency of museums and cultural reserves, which are not only unable to organize the display and effective use of their existing historical objects and buildings, but can not even ensure their preservation and prevent their destruction; e) the lack of response of the Ministry of Culture, the police and other state authorities to violations of laws on the protection of cultural heritage, their lack of response to situations that may lead to damage or complete loss of cultural heritage objects, the inability of state and municipal structures to stopping illegal actions in the field of heritage protection.

A large scale reform of the system of cultural heritage public management in Ukraine is very relevant and necessary to preserve the existing cultural heritage and transmit it to future generations. Without public management reform cultural heritage will continue to degrade and disappear forever. Only drastic measures can slow down this process, but it is better to stop it and reverse it. This is a complete registration of Ukraine's cultural heritage (creating the most complete, public, informative and interactive registry). It also includes resolving issues of land use and status of historic and cultural territories, securing obligations to protect historical buildings by their owners, and tough penalties for non-compliance. In addition, museums and cultural reserves require large investments, and their effective functioning requires careful and thoughtful cooperation with businesses. All these measures should be supplemented by increasing the overall effectiveness of public management, police and Prosecutor's offices, which should promptly detect violations, effectively prevent illegal actions and ensure that all violators of the law are punished.

\section{REFERENCES:}

1. Accounting Chamber of Ukraine (2015). The decision on the results of the audit of the effectiveness of the use of state budget funds allocated to the Ministry of Culture of Ukraine for the preservation of historical and cultural heritage in the reserves, the implementation of measures for the protection, certification, inventory and restoration of cultural heritage monuments. URL: https://rp.gov.ua/upload-files/activity/collegium/2015/zvit_9-1_2015/r_rp_9-1.pdf

2. Bohutskyy, Y. (ed.) (2009). Heritage Studies: Legal Protection of Cultural Property: Collection of Documents. Kyiv: Instytut kulturolohiyi Akademiyi mystetstv Ukrayiny.

3. Cabinet of Ministers of Ukraine (2000). Resolution approving the Regulations on the Museum Fund of Ukraine. URL: https://zakon.rada.gov.ua/laws/show/1147-2000-\%d0\%bf

4. Cabinet of Ministers of Ukraine (2010). Resolution on amendments to the Regulations on the Museum Fund of Ukraine. URL: https://zakon.rada.gov.ua/laws/show/1007-2010-\%d0\%bf 
5. Cabinet of Ministers of Ukraine (2014). Resolution on the issue of introducing restrictions on the conduct of inspections by state inspections and other regulatory authorities. URL: https://zakon.rada.gov.ua/laws/ show/408-2014-\%d0\%bf

6. Constitution of Ukraine (1996). URL: https://iportal.rada.gov.ua/uploads/documents/27396.pdf

7. Ganski, U. (2018). Public administration of heritage resources in the territorial community participation system. The Formation of a Mechanism for Public Administration of Rural Territories' Development as a Priority of the State Decentralization Policy: International Scientific Conference Proceedings, Zhytomyr, 2018. 4 December. URL: http://znau.edu.ua/images/images-news/2019/01/zbirnik04122018_тановл_мех.pdf

8. Ganski, U. (2019). Actual problems of registration and management of historical and cultural heritage in Ukraine. XIIIth Ranamaŭ Readings: International Scientific Conference Proceedings, Mogilev, 2019. 25-26 October. URL: https://libr.msu.by/bitstream/123456789/8322/1/1859s.pdf

9. Harnyk, M. (ed.) (2002). Cultural heritage of Ukraine. Legal principles of preservation, reproduction and protection of cultural and historical environment. Kyiv: Istyna.

10. Kazlouski, V., and Ganski, U. (2018). Modern problems and features of management of historical heritage institutions in the context of increasing their service nature. Prychornomorski Ekonomichni Studiyi 29: 93-98. URL: http://nbuv.gov.ua/ujrn/bses_2018_29(1)_21

11. Kharkovenko, R. (2017). History of the development of registration documentation for objects of cultural heritage in Ukraine. International Journal of Legal Studies, 2: 329-344.

12. Kovalskyy, V. (2020). Cathedral or skyscraper: Sophia of Kyiv is threatened by a developer. Vechirniy Kyyiv. February 3, 2020. URL: https://vechirniy.kyiv.ua/news/sobor-chy-khmarochos-sofii-kyivs-kiy-zahrozhuye-zabudovnyk

13. Kyiv City Council (2005). Measures on implementation of public hearing resolutions on the conservation of the historical building, natural reserved areas and organization of the green places of community use. URL: http://kmr.ligazakon.ua/SITE2//_docki2.nsf/alldocwww/7f22859dfeee7efbc22573c00052fed8?opendocument

14.Kyiv City Council (2015). Decision on the introduction of a temporary ban (moratorium) on the construction and sale of land plots within the protection (buffer) zones of Kyiv. URL: http://kreschatic.kiev.ua/ua/4588/doc/1426096692.html

15. Law of Ukraine (1995). On Museums and Museum Activity Vidomosti Verkhovnoyi Rady Ukrayiny, 25: 191. URL: https://zakon.rada.gov.ua/laws/show/249/95-\%d0\%b2\%d1\%80

16. Law of Ukraine (2000). On the cultural heritage protection. Vidomosti Verkhovnoyi Rady Ukrayiny, 39: 333. URL: https://zakon.rada.gov.ua/laws/show/1805-14

17. Law of Ukraine (2007). On the basic principles of state supervision (control) in the field of economic activity. Vidomosti Verkhovnoyi Rady Ukrayiny, 29: 389. URL: https://zakon.rada.gov.ua/laws/show/877-16

18. Law of Ukraine (2009). About Non-Privatization List of Cultural Heritage Sites. Vidomosti Verkhovnoyi Rady Ukrayiny, 8: 105. URL: https://zakon.rada.gov.ua/laws/show/574-17

19. Mazur, T.V. (ed.) (2018). Information and analytical materials for parliamentary hearings on the state, problems and prospects of cultural heritage protection in Ukraine. Kyiv: Cabinet of Ministers of Ukraine.

20. Ministry of Culture of Ukraine (2020). State Register of Immobile Heritage Monuments of Ukraine. URL: http://mincult.kmu.gov.ua/control/uk/publish/officialcategory?cat_id=244910406

21. National Standard of Ukraine (2017). The Composition and Content of Project Documentation for the Definition of Boundaries and Usage Regimes of Zones of Protection of Architecture and Urban Planning Heritage Monuments. URL: http://ndpi.com.ua/articles/28.pdf

22. Polyvach, K. (2012). Cultural heritage and its influence on the development of regions of Ukraine. Kyiv: Instytut heohrafiyi NAN Ukrayiny.

23. Radio Liberty (2009). Khortytsia Land. Khortytsia Island is under threat. URL: https://www.radiosvoboda.org/ a/1901512.html

24.Radio Liberty (2017). Kyiv Pechersk Lavra: restructuring (investigation). URL: https://www.radiosvoboda.org/ a/28556722.html 